\title{
Correspondence
}

CHI. \& WTO ReV. 2016:2; 369-380

http://dx.doi.org/10.14330/cwr.2016.2.2.10

pISSN 2383-8221 • elSSN 2384-4388

China and WTO Review

\section{Transcontinental Railway: Peru-Brazil (FETAB)}

\author{
Adriana G. Quintero R.
}

\section{Overview: Chinese investment in Latin America}

For several centuries the largest volume of world trade carried was across the Atlantic Ocean. However, that began to change with the growth of Asian economies, especially China, leading Asia-Pacific trading to represent 60 percent of today's world trade. ${ }^{1}$ China has been continuously maintaining large investments throughout the world that could ultimately help achieve its economic development. Latin America is not an exception to this phenomenon; this Asian giant for being a region rich in mineral resources and agricultural products. ${ }^{2}$

Recently, Chinese-Latin American relations are continuously deepening through closer economic ties. The Inter-American Dialogue database estimates that since 2005, China has granted more than USD 125 billion in loans throughout Latin America. ${ }^{3}$ This trend is expected to continue considering that Chinese President $\mathrm{Xi}$ Jinping has agreed to invest USD 250 billion over the next 10 years in January 2015 . Such investment was intended specifically to increase China's influence in the region.

In September 2015, the Central Bank of China announced the establishment of an investment fund of USD 10,000 million in countries such as Ecuador, Venezuela, Nicaragua, Peru, Brazil, Chile, Bolivia and Argentina for bilateral cooperation in areas of high technology, energy, mining and infrastructure

\footnotetext{
* Attorney-at-Law (Venezuela Bar); Legal Counsel of the Venezuelan Embassy in Korea; LL.M. candidate of Dongguk University, Seoul, Korea. LL.B.(Univ. of Rafael Belloso Chacin). She may be contacted at: aadrianagquintero@gmail.com
} 
projects. $^{6}$ Among them, the most ambitious project in Latin America is to construct the Transcontinental Railroad which aims to link the Atlantic and the Pacific oceans in order to improve internal transport of raw materials and its export to other countries.

\section{A Grand Design: The Transcontinental Railroads}

The Transcontinental Railroad, known by its Spanish acronym FETAB, is a combined working project initiated by Brazil and Peru, together with the People's Republic of China. The proposal to create a railway of such magnitude was actually triggered by an American engineer H. A. Cooper who in 1953 designed a map of what, in his opinion, would become the global network of railways. Today, such a utopian project is taking its first steps in South America.

Figure 1: Main Lines of a Worldwide Rail Network, As Sketched by H.A. Cooper ${ }^{7}$

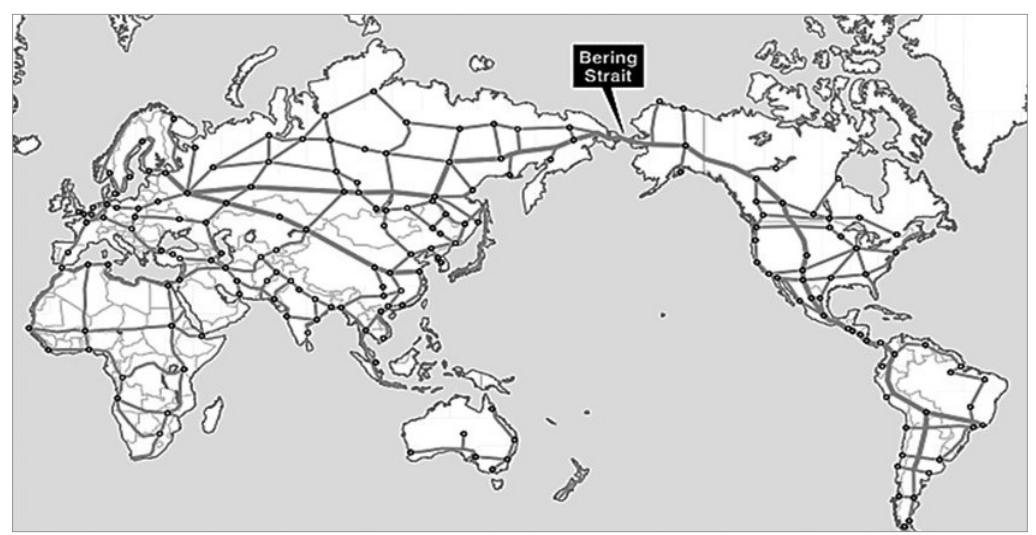

The construction of the transcontinental railroad would pass through the Brazilian state of Rondonia starting in the municipalities of Porto Velho and Vilhena. The route would also include the states of Goias and Mato Grosso and reach the border with Peru by Acre, according to VALEC Engenharia, Construções e Ferrovias S.A. (Engineering, Construction and Ferrovías SA), a public company associated with the Ministry of Transport, Brazil. ${ }^{8}$ 
Figure 2: Possible route of the Transcontinental Railroad linking the Atlantic Ocean and the Pacific ${ }^{9}$

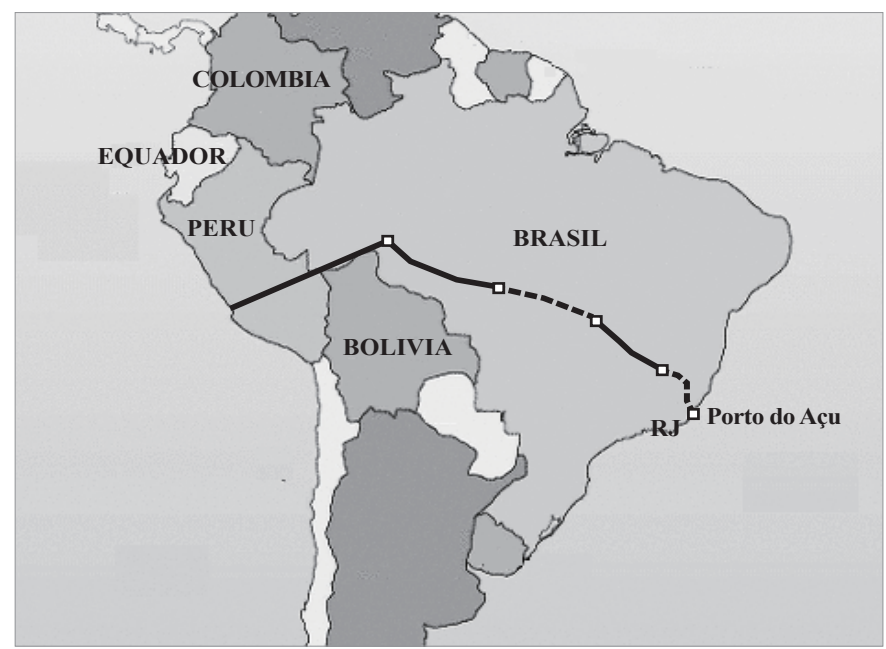

Source: Compiled by the author.

On the Peruvian side, the path will start from the town of Boqueirao da Esperanca, Cruceiro do Sol, State of Acre in the Federal Republic of Brazil, and conclude in the ports of Paita and Bayóvar in the provinces of Paita and Sechura, respectively, of the department of Piura. It will be connected with the railway of Cerro de Pasco, leading to the Port of Callao in the Constitutional Province Callao, as stated in Law No. 29207 enacted by the Peruvian Congress. ${ }^{10}$

\section{Progress}

The Railroad project is in the initial stage of conducting feasibility studies, ${ }^{11}$ as announced by Brazilian President Dilma Rousseff and Chinese Premier Li Keqiang in 2015. ${ }^{12}$ The construction of the Transcontinental Railroad is expected to complete in approximately 6 years; taking into account the path of Brazil which already has constructed roads. ${ }^{13}$ Stretching $901 \mathrm{~km}$, the Transcontinental Railroad was previously planned to transport grains, primarily soy and corn, from north central state of Mato Grosso, the main producing region of soybean in Brazil equivalent to 10 percent of the world production of this grain - toward the main 
ports of the country. ${ }^{14}$

The construction of this section was completed in two stages: The first in December 2010, covering the segment of Campinorte to Água Boa; and the second in February 2012, from Água Boa to Lucas do Rio Verde. ${ }^{15}$

Figure 3: Line Diagram of the Transcontinental Railroad ${ }^{16}$

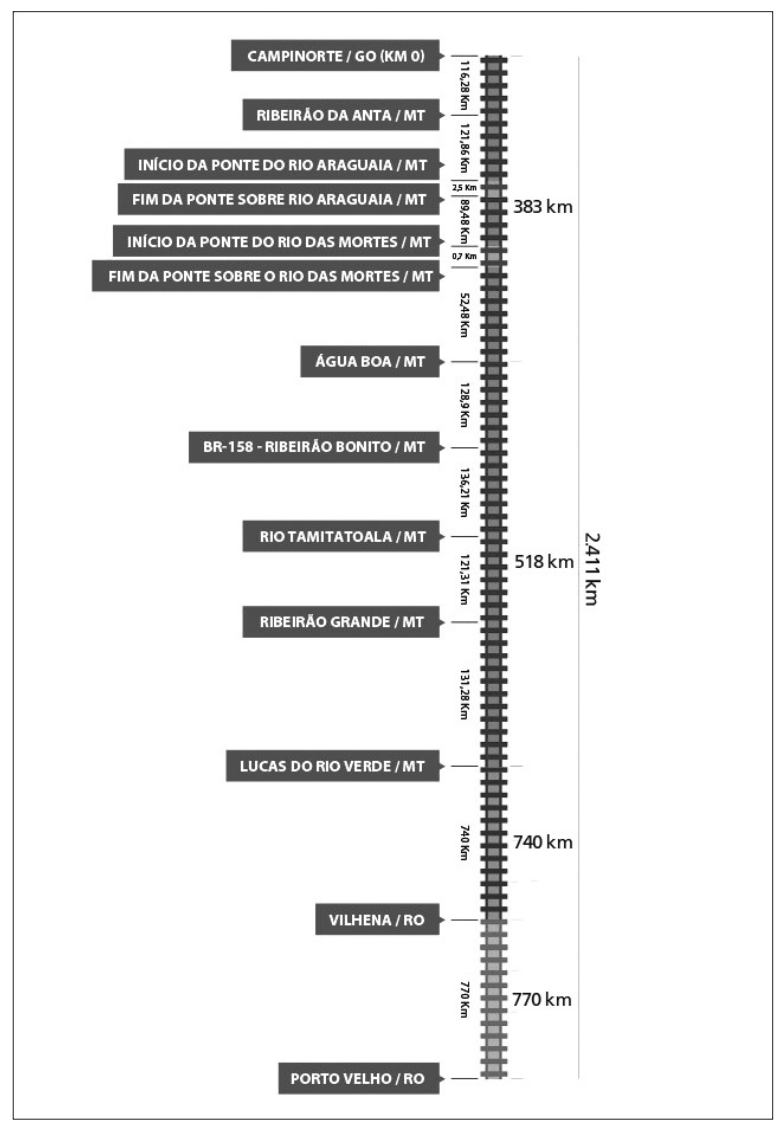

Regardless of the challenges these three countries are currently facing, they have reached an agreement to accelerate the realization of this project by working together to achieve a breakthrough. They are willing to promote economic development and speed up industrialization and urbanization along the regions where the railway line will pass. ${ }^{17}$ 


\section{Investment}

The Peruvian ministerial resolution lays great emphasis on the granting of temporary concessions to investors and their partners, who will demonstrate both economic grounding through the capital, and technical capacity through experience of design, construction and operation of tracks. ${ }^{18}$

On this matter, the president of the Association of Chinese Enterprises in Peru, Bencai Gong, announced that China International Water \& Electric Corporation is one of the parties involved in the project. ${ }^{19}$ Overall, this project will be receiving financial support from China's Development Bank if the construction is carried out by local companies, and these two corporations. ${ }^{20}$

\section{Legal Ground}

The presidents of Brazil, Peru and China signed two Memorandums of Understanding; one to build the transcontinental railroad and the other to set guidelines to be followed upon the realization of the feasibility studies. ${ }^{21}$ Accordingly, an agreement in action was signed between Brazil's Ministry of Transport, Peru's Ministry of Transport and Communications, and the Chinese National Commission of Development and Reform. This agreement is expected to deliver the project of over approximately 5,300 kilometers at an estimated cost of USD 10 billion. $^{22}$

Meanwhile, Peru has its own legal instruments addressing this topic. First, the Peruvian Congress enacted Law No. 29207 declaring this project of national interest and public necessity. ${ }^{23}$ It is accompanied by a set of rules and a ministerial resolution which approved the technical guidelines that should be considered in the preparation of feasibility studies for the execution of FETAB. ${ }^{24}$

Law No. 29207 is very short in its content, mainly focusing on the provision of guidelines to be followed by investors. Article 2 provides:

The development of the feasibility studies, operation and maintenance of the road, as well as the expenses arising from the acquisition and/ or expropriation of the means necessary for the execution of the works of FETAB project will be assumed entirely by the investor [to whom will be granted a temporary concession of two years for the preparation of these studies]. ${ }^{25}$ 
The rules contain procedures and deadlines for granting this temporary concession and the specific provisions relating to the promotion, allocation and supervision of the project. While the Ministerial Resolution addresses the topic in a more comprehensive manner referring to points such as the accreditation of the investor, the deadline for the execution of the project, settlement of disputes, applicable law, arbitration, among others. ${ }^{26}$

\section{Economic Benefits}

This project is expected to be helpful to link South America through the East-West corridors, thereby reducing export costs and time taken logistically between Peru, Brazil and overseas. It will also represent another form of transportation, besides the Panama Canal, and improve commercial trade between these countries.

Orlando Fontes Lima, professor of logistics and transport at State University of Campinas in Sao Paulo maintains that it takes about 30 and 40 days for a ship carrying grain from the ports of Santos, Paranaguá or Belem, normally to reach China, but through the transcontinental railway it would be possible to reduce the time of transporting products from Brazil to China by about 30 to 40 percent. $^{27}$ This project is also very enticing for Brazil who could achieve inner cargo transportation by rail. Moreover, Latin America's infrastructure could be improved for its economic development. On the other hand, the output of its railway equipment and technology could be the key to incrementing China's export trade.

\section{Social Cost}

\section{A. Human Rights}

Some experts are afraid of possible human rights violation of indigenous people considering that the railway would pass through sensitive areas. ${ }^{28}$ In the drawing course between Port of Açu, in Rio de Janeiro, and Port of Ilo, on the Peruvian coast, there are significant regions home to indigenous group such as Eco Cerrado, Amazon Forest, and several national parks. It is feared that the railway line could indirectly inflict the deforestation of these areas and cause damage to the people there. However, the presidents of these three nations concurred with the fact that the joint feasibility study will not only be in favor of the railroad's development 
but also for ecological assurance. ${ }^{29}$

\section{B. Environmental Risk}

Sometimes the social and environmental cost of a project can be much greater than the cost of the works. Paulo Adario, a strategist for the ONG Greenpeace for the protection of the forest, said: "By making a channel to the Pacific you open the Amazon to the Chinese market [...] It would be an illusion to believe that this will not have an impact. ${ }^{, 30}$

Roberto Maldonado, specialist for the World Wide Fund for Nature ("WWF") in South America, stated that:

An investment of this kind is not without consequences for the environment. Depending on the route, the nature of the place will be affected to a greater or lesser extent. It is possible that the areas protected by the government, such as indigenous territories, become directly affected by the project. ${ }^{31}$

Even if its technical feasibility is found, there would be strong resistance from civic societies along with environmental NGOs in the course of realizing FETAB. Their biggest question is to obtain environmental licenses in order to avoid making the work non-viable.

With a different set of ideas, Adriano Pires, director of the Brazilian Center for Infrastructure ("CBIE") declared that: "From the environmental point of view, the most advanced rail technologies have a low impact on the environment." Marcos Troyjo, director of the BRICLab at Columbia University agreed by stating: "No country in the world has seriously threatened its environmental heritage by the expansion of the rail network." ${ }^{32}$ In this sense, Vega Alvear, president of the Binational Chamber of Commerce and Integration between Peru and Brazil, concluded: "A railroad reduces the environmental problems of a common road because of its established stops; it wouldn't stop everywhere as vehicles do.",33

In the end, the railway line should pay special attention to not affect protected areas and communities near the route, making this their first priority. 


\section{Conclusion}

The construction of the Trans-Oceanic Railroad will provide China with a great advantage in Latin America. First, shippers would finally have the capacity to transport soybeans and other type of merchandise from Brazil to ports in Peru for trade to China and Chinese products the other way around. It could not only sidestep the expensive and congested Panama Canal, but even circumvent the new Nicaragua Canal additionally being worked by the Chinese. Moreover, China needs to maintain its financial extension, while it keeps signing infrastructure contracts all over the world. ${ }^{34}$ As for Peru and Brazil, counted are the benefits these two countries could be receiving thanks to this project. However, as mentioned before, both countries could face human and environmental problems by its construction.

Without concrete solutions for these questions, this mega project might negatively affect Latin American societies. The people in charge of this project should avoid committing the mistake of rushing, while also carefully listening to environmental alerts and encouraging consultation with local people, especially ethnic groups concentrated in sensitive areas of construction. Christian Poirier of Amazon Watch said: "Past mega-projects suggest that far from consulting the indigenous communities that lay in their path, the government is more likely to steamroll their rights while paying mere lip service to environmental protection." ${ }^{35}$ Thereupon, it would be righteous to follow the advice of environmental experts, meeting guidelines established for the protection of the environment laws of each country, and holding on to the best practices from the planning stage all the way through to the completion of the railway. ${ }^{36}$ Unless overcoming environmental risks the Transcontinental Railroad could finally cease to exist only on paper.

\section{REFERENCES}

1. R. Mendoza, The train China wants [El Tren Que China Quiere], LaRepublica.Pe, May 24, 2015, available at http://arepublica.pe/impresa/politica/2267-el-tren-que-china-quiere (last visited on Aug. 5, 2016).

2. G. Lissardy, The Controversial Atlantic-Pacific Railway China wants to build in South America [El Polémico Tren Atlántico-Pacífico Que China Quiere Construir En Sudamérica], BBC 
Mundo, May 18, 2015, available at http://www.bbc.com/mundo/noticias/2015/05/150518_ brasil_peru_china_tren_bioceanico_gl (last visited on Aug. 5, 2016).

3. P. Gallagher \& M. Myers, China-Latin America Finance Database, Washington: InterAmerican Dialogue (2014), available at http://www.thedialogue.org/map_list (last visited on July 30, 2016).

4. M. Rajagopalan, China's Xi Woos Latin America with $\$ 250$ Billion Investments, Reuters, Jan. 8, 2015, available at http://www.reuters.com/article/us-china-latamidUSKBN0KH06Q20150108 (last visited on July 30, 2016).

5. M. Miller, China and Peru considering Rail Link across Brazil, Sydney Morning Herald, May 25, 2015, available at http://www.smh.com.au/world/china-and-peru-considering-raillink-across-brazil-20150525-gh8v08.html\#ixzz49ZTSDMpF (last visited on Aug. 5, 2016).

6. China Launches Fund for LatAm Industrial Cooperation, XinHuANET, Sept. 1, 2015, available at http://news.xinhuanet.com/english/2015-09/01/c_134577360.htm. See also M. Ilyásova \& I. Serbinov, China to conquer Latin America [China a La Conquista De Latinoamérica], RT, Nov. 21, 2015, available at https://actualidad.rt.com/actualidad/192245-china-inversionesproyectos-america-latina (all last visited on Aug. 5, 2016).

7. H. Cooper, Bring The Eurasian Land-Bridge To America, 28 Executive Intelligence Rev., Oct. 19, 2001, at 11 (Figure 1), available at http://www.larouchepub.com/eiw/public/2001/ eirv28n40-20011019/eirv28n40-20011019_010-hb_cooper.pdf (last visited on Aug. 5, 2016).

8. VALEC, Actions and Programs [Ações E Programas]: Map 24 - passage Campinorte/GOAgua Boa/MT-Lucas do Rio Verde/MT-Vilhena/RO-Porto Velho/RO, available at http:// www.valec.gov.br/acoes_programas/FerroviaTranscontinental.php (last visited on Aug. 5, 2016).

9. See The controversial Atlantic-Pacific train that China wants to build in South America [E1 polémico tren Atlántico-Pacífico que China quiere construir en Sudamérica], May 18, 2015, BBC Mundo (Brazil) available at http://www.bbc.com/mundo/noticias/2015/05/150518_ brasil_peru_china_tren_bioceanico_gl (last visited on Aug. 5, 2016).

10. See Law Declaring of Public Need and National Interest the Construction of the Transcontinental Railroad "Brazil-Peru” Atlantic-Pacific [Ley que Declara de Necesidad Pública y de Interés Nacional la Construcción de la Ferrovía Transcontinental "BrasilPerú” Atlántico-Pacífico (Fetab)], art. 1, available at http://www2.congreso.gob.pe/Sicr/ RelatAgenda/proapro.nsf/0de6d4a383ac8e9005256b76007bde47/187885777ba7b9fd05257 41100593025/\$FILE/1555.pdf (last visited on Aug. 5, 2016).

11. R. Mendoza, The train China wants [El Tren Que China Quiere], LaRepublica.PE, May 24, 2015, available at http://larepublica.pe/impresa/politica/2267-el-tren-que-china-quiere (last visited on Aug. 5, 2016).

12. See Rousseff and Li Keqiang announced studies for transoceanic train Brazil-Peru [Rousseff y Li Keqiang anuncian estudios para tren transoceánico Brasil-Perú], ABC.ES, May, 19, 2015, available at http://www.eldiario.es/politica/Rousseff-Li-Keqiang-transoceanico- 
Brasil-Peru_0_389511971.html (last visited Aug. 5, 2016).

13. Supra note 8.

14. VALEC, Actions and Programs [Ações E Programas]: Passage Campinorte/GO-Agua Boa/ MT-Lucas do Rio Verde/MT, available at http://www.valec.gov.br/acoes_programas/ FTCampinorteAguaBoaLucas.php (last visited on Aug. 5, 2016).

15. Id.

16. Supra note 8 .

17. See China, Brazil and Peru agree to conduct feasibility study on Transcontinental Railroad China, [Brasil Y Perú Acuerdan Realizar Estudio De Viabilidad Sobre Ferrocarril Transcontinental], AmÉRICA ECONOMíA, May 25, 2015, available at http://www. americaeconomia.com/negocios-industrias/china-brasil-y-peru-acuerdan-realizar-estudiode-viabilidad-sobre-ferrocarril-tr (last visited on Aug. 5, 2016).

18. Ministerial Resolution approves the technical guidelines that describe the minimum conditions that must be considered in the preparation of technical studies for the execution of works, maintenance and operation of the Transcontinental Railroad Project "Brazil-Peru" (FETAB). See the official document of Peruvian Ministry of Transport and Communication, available at http://www.mtc.gob.pe/portal/home/PROYECTO_NORMA_CONCE_ PUBLICACION.pdf (last visited on at Aug. 6, 2016).

19. The corporation is a subsidiary of the China Three Gorges Corporation, which is a company of great trajectory known for its experience in hydroelectric projects, highways, and railways in more than 30 countries. See F. Ortiz, Brazil, Peru and China and the Interoceanic Dream, DiÁlogo Chino, Feb. 5, 2015, available at http://dialogochino.net/china-ispart-of-an-interoceanic-dream-between-brazil-and-peru (last visited on at Aug. 5, 2016).

20. J. Watts, China's Amazonian Railway 'threatens Uncontacted Tribes' and the Rainforest, GuARDian, May 16, 2015, available at https:/www.theguardian.com/world/2015/may/16/ amazon-china-railway-plan (last visited on at Aug. 5, 2016).

21. See Bioceanic railway connection, Memorandum of Understanding between Brazil, China and Peru [Conexión ferroviaria bioceánica. memorándum de entendimiento entre Brasil, China y Perú], Inventariando China, May 19, 2015, available at https://inventariandochina. com/2015/05/19/conexion-ferroviaria-bioocaenica-memorandum-de-entendimiento-entrebrasil-china-y-peru/\#comments (last visited on Aug. 5, 2016).

22. Supra note 19.

23. Law Declaring of Public Need and National Interest the Construction of the Transcontinental Railroad "Brazil-Peru" Atlantic-Pacific, or Law of Transcontinental Railroad [Ley que Declara de Necesidad Pública y de Interés Nacional la Construcción de la Ferrovía Transcontinental "Brasil-Perú" Atlántico-Pacífico (Fetab)], available at http://www2. congreso.gob.pe/Sicr/RelatAgenda/proapro.nsf/0de6d4a383ac8e9005256b76007bde47/187 885777ba7b9fd0525741100593025/\$FILE/1555.pdf (last visited on Aug. 5, 2016).

24. Supra note 18. 
25. Law of Transcontinental Railroad art. 2.

26. Supra note 18.

27. F. Caulyt, The Environmental Barriers of the Transoceanic Railway [La Ferrovía Transoceánica, Ante Obstáculos Ambientales], DW: América Latina, May 26, 2015, available at http://www.dw.com/es/la-ferrovía-transoceánica-ante-obstáculos-ambientales/ a-18477442 (last visited on Aug. 5, 2016).

28. Supra note 2.

29. Supra note 17.

30. Supra note 2.

31. Supra note 27.

32. Id.

33. Supra note 1.

34. R. Walker, Chinese Commit $\$ 10$ Billion to Build Train from Peru to Brazil, CHINA-US Focus, May 26, 2015, available at http://www.chinausfocus.com/finance-economy/chinesecommit-10-billion-to-build-train-from-peru-to-brazil (last visited on at Aug. 5, 2016).

35. Supra note 20.

36. J. Bicknell, China's Trans-Amazonian Railway Might Be the Lesser of Two Evils, Conversation, June 19, 2015, available at http://theconversation.com/chinas-transamazonian-railway-might-be-the-lesser-of-two-evils-43075 (last visited on at Aug. 5, 2016). 
